\title{
Correction to: Recommendations of RILEM TC 260-RSC for using superabsorbent polymers (SAP) for improving freeze-thaw resistance of cement-based materials
}

\author{
Viktor Mechtcherine (D) Christof Schröfl - Michaela Reichardt • \\ Agnieszka J. Klemm $\cdot$ Kamal H. Khayat
}

Published online: 17 March 2020

(C) RILEM 2020

Correction to: Materials and Structures (2019) 52:75

https://doi.org/10.1617/s11527-019-1375-4

Agnieszka J. Klemm is affiliated to Glasgow Caledonian University, Glasgow, UK.
Publisher's Note Springer Nature remains neutral with regard to jurisdictional claims in published maps and institutional affiliations.

The original article can be found online at https:// doi.org/10.1617/s11527-019-1375-4.

V. Mechtcherine $(\bowtie) \cdot$ C. Schröfl $\cdot$ M. Reichardt Technische Universität Dresden, Dresden, Germany e-mail: viktor.mechtcherine@tu-dresden.de

A. J. Klemm

Glasgow Caledonian University, Glasgow, UK

K. H. Khayat

Missouri University of Science and Technology, Rolla, USA 